\title{
Evaluation of vehicular pollution using the TRAD-MCN mutagenic bioassay with Tradescantia pallida (Commelinaceae) ${ }^{\text {is }}$
}

\author{
Aline do Nascimento Rocha ${ }^{a}$, Liliam Silvia Candido ${ }^{b}$, Joelson Gonçalves Pereira ${ }^{b}$, \\ Caio Augusto Mussury Silva c, Sandra Verza da Silva d, **, Rosilda Mara Mussury a, b, * \\ a Laboratory of Botanical Application, PostGraduate Program in General Biology/Bioprospecting, Faculty of Biological and Environmental Sciences, Federal \\ University of Grande Dourados, Rodovia Dourados-Itahum, KM 12, 79.800-000, Dourados, Mato Grosso Do Sul, Brazil \\ ${ }^{\mathrm{b}}$ Faculty of Biological and Environmental Sciences, Federal University of Grande Dourados, Rodovia Dourados-Itahum, KM 12, 79.800-000, Dourados, Mato \\ Grosso Do Sul, Brazil \\ ${ }^{\mathrm{c}}$ Federal University of Minas Gerais, Faculty of Medicine. Antônio Carlos, 6627, Pampulha, Belo Horizonte, MG, Brazil \\ ${ }^{\mathrm{d}}$ Department of Vegetal Production, Phytosanitary Defense, Faculty of Agronomic Sciences, São Paulo State University, Street José Barbosa de Barros, 18610- \\ 307, Botucatu, São Paulo, Brazil
}

\section{A R R T I I C L E E I N F}

\section{Article history:}

Received 7 October 2017

Received in revised form

14 April 2018

Accepted 21 April 2018

Available online 10 May 2018

\section{Keywords:}

Atmospheric pollution

Bioindicator

Micronucleus

Motor-vehicles

\begin{abstract}
A B S T R A C T
Biomonitoring is one of the tools used to assess the mutagenic potential of the atmosphere. In this study, the mutagenicity of Tradescantia pallida, a species of plant largely present in urban environments, was investigated. The objectives of this study was to estimate the mutagenic potential of vehicular flow through the TRAD-MCN bioassay in cities located at different altitudes in the southwest mesoregion of Mato Grosso do Sul, Brazil, to infer possible abiotic agents that may contribute to the effects of atmospheric pollutants, and finally to map the cities with greater risks to the health of the local population. To achieve these objectives, the Tradescantia-micronucleus test was performed on young buds of T. pallida collected between August 2015 and August 2016 in nine cities of Mato Grosso do Sul. These buds were exposed to traffic flows of various intensities. The data collected consisted of measurements of meteorological parameters and vehicular traffic counts for each city. The variables considered were: mean ambient temperature; micronuclei frequency; vehicular flow; altitude; relative humidity; pluviosity. The application of the Trad-MCN bioassay, with the consideration of environmental variables and altitudes, and the use of the Kernel interpolation technique, allowed us to map the areas with significant pollution risks to the population. The highest frequency of exposure to mutagens occurred in the cities with the highest vehicular traffic intensity. The average ambient temperature failed to show a linear association with the frequency of the micronuclei in the samples analyzed $\left(r=0.11^{\mathrm{ns}}\right)$. A positive correlation was observed between micronuclei frequency and vehicular flow, $(r=0.67 ; p \leq 0.001 \%)$ and between micronuclei frequency and altitude $(\mathrm{r}=0.24 ; \mathrm{p} \leq 0.05)$. A negative correlation was found between relative humidity and micronuclei frequency $(\mathrm{r}=-0.19 ; \mathrm{p} \leq 0.05 \%)$. Thus, higher micronuclei frequency tended to be present in locations with low relative humidity and high altitudes and vehicular flow.
\end{abstract}

(c) 2018 Elsevier Ltd. All rights reserved.

\footnotetext{
4t This paper has been recommended for acceptance by David Carpenter.

* Corresponding author. Laboratory of Botanical Application, PostGraduate Program in General Biology/Bioprospecting, Faculty of Biological and Environmental Sciences, Federal University of Grande Dourados, Rodovia Dourados-Itahum, KM 12, 79.800-000, Dourados, Mato Grosso Do Sul, Brazil.

** Corresponding author.

E-mail addresses: aline_2402@hotmail.com (A.N. Rocha), liliamcandido@ufgd. edu.br (L.S. Candido), joelsonpereira@ufgd.edu.br (J.G. Pereira), caiomussury@ gmail.com (C.A.M. Silva), sandraverza@yahoo.com (S.V. da Silva), maramussury@ ufgd.edu.br (R.M. Mussury).
}

\section{Introduction}

Air pollution is a major threat to human health, potentially leading to chronic cardiovascular and respiratory diseases (Dapper et al., 2016; Gouveia et al., 2017; Nascimento et al., 2017). Moreover, air pollution impairs genetic stability, contributes to mutations in the DNA, and increases the risk of cancer (Lewtas, 1993; Boström et al., 1994; Cohen et al., 2004; IARC, 2016). In particular, the respiratory system can be negatively impacted, and this risk is higher for individuals living in urban areas (Nyberg et al., 2000; Wen Cheng and Lee, 2003; Bernstein et al., 2004). 
Atmospheric pollution is a consequence of growing urbanization, development of the agricultural sector, and the increasing use of automotive vehicles and other technologies that utilize combustion engines. These activities produce genotoxic agents that, when released into the atmosphere, combine with other compounds present in the air and affect the quality of life of the population (Vargas, 2003; Claxton and Woodall, 2007; Ianisticki et al., 2009; Pereira et al., 2010; Brito et al., 2013). The air in urban areas contains several potentially carcinogenic particles, such as polycyclic aromatic hydrocarbons (PAHs), benzene, and arsenic. These substances are the result of the incomplete combustion of fossil fuels that are widely used in combustion engines and in industrial activities (Mišik et al., 2006).

Studies conducted in urban areas indicate that many of the mutagenic compounds that are present in the air surrounding the Asian, European and American continents, come from automotive diesel and gasoline, as well as other sources of combustion (Claxton et al., 2004). Exhaust from diesel engines (IARC, 2013) and coal emissions (IARC, 2010) are among the most significant sources of human carcinogens. According to IARC (2016), there is a dosedependent effect on the amount of mutagenic compounds found and the micronuclei frequency found in every study analyzed.

Economic development in the mid-western region of Brazil is strongly associated with activities in the agricultural sector, having solid foundations in agribusiness (Fagundes et al., 2017). Due to the flow of agricultural products from the south of Mato Grosso do Sul to other states, heavy vehicular traffic has gradually increased, and this has altered the air quality in the microregion of Grande Dourados, the second largest city of the state. This was verified using biomonitoring with Tradescantia pallida (TRAD-MCN) by Crispim et al. (2012; 2014), and a comet assay was utilized by Spósito et al. (2015; 2017).

In places with a tropical climate, the clone 4430 has been substituted for T. pallida in biomonitoring approaches, with satisfactory results in comparative studies (Mielli et al., 2009). In addition, the micronucleus test is a complementary tool in the evaluation of the air quality of a region (Santos et al., 2015; Spósito et al., 2015, 2017; Da Costa, 2016).

The Trad-MCN test estimates the micronuclei frequency, which result from whole chromosomes or fragments of chromosomes that, because they do not bind to the spindle fibers, are not included in the nuclei of the daughter cells. Instead, they remain in the cytoplasm of the interphase cells, where they are observed (Meireles and Cerqueira, 2011). Tradescantia has been used experimentally since the first studies that related genetic activity with the action of chemical compounds and agents (Ma, 1981, 1983; Grant et al., 1992; Klumpp et al., 2004). Virtually all parts of this plant can compose mutagenesis bioassays for the detection and monitoring of environmental pollution (Grant, 1998). The micronucleus test with Tradescantia spp. (Trad-MCN) is considered one of the most sensitive, efficient and recommended for the detection of genotoxic agents in air (Ma, 1981, 1983; Ennever et al., 1988; Rodrigues et al., 1997; Saldiva et al., 2002; Misík et al., 2007; Andrade et al., 2008; Crispim et al., 2012, 2014 and Spósito et al., 2015, 2017).

In studies conducted in the cities of Mato Grosso do Sul, Crispim et al., 2012, 2014 and Spósito et al. (2015, 2017) found a higher frequency of pollutant affected micronuclei in the cities of Dourados, Rio Brilhante, and Caarapó. They noted that the intensity of the traffic flow resulted in damage to the genetic material and changes in the leaf structure of T. pallida.

Studies that compare cities that are potentially exposed to air pollutants, and the populations living in those areas, can be used to create a database. This database can then be used to compare the effects on local populations, the health of the inhabitants, and the dynamics of energy use in a particular city.

Motivated by the aforementioned information, the present study had the objective of estimating the mutagenic potential of the vehicular flow through the TRAD-MCN bioassay in cities located at different altitudes in the southwest mesoregion of Mato Grosso

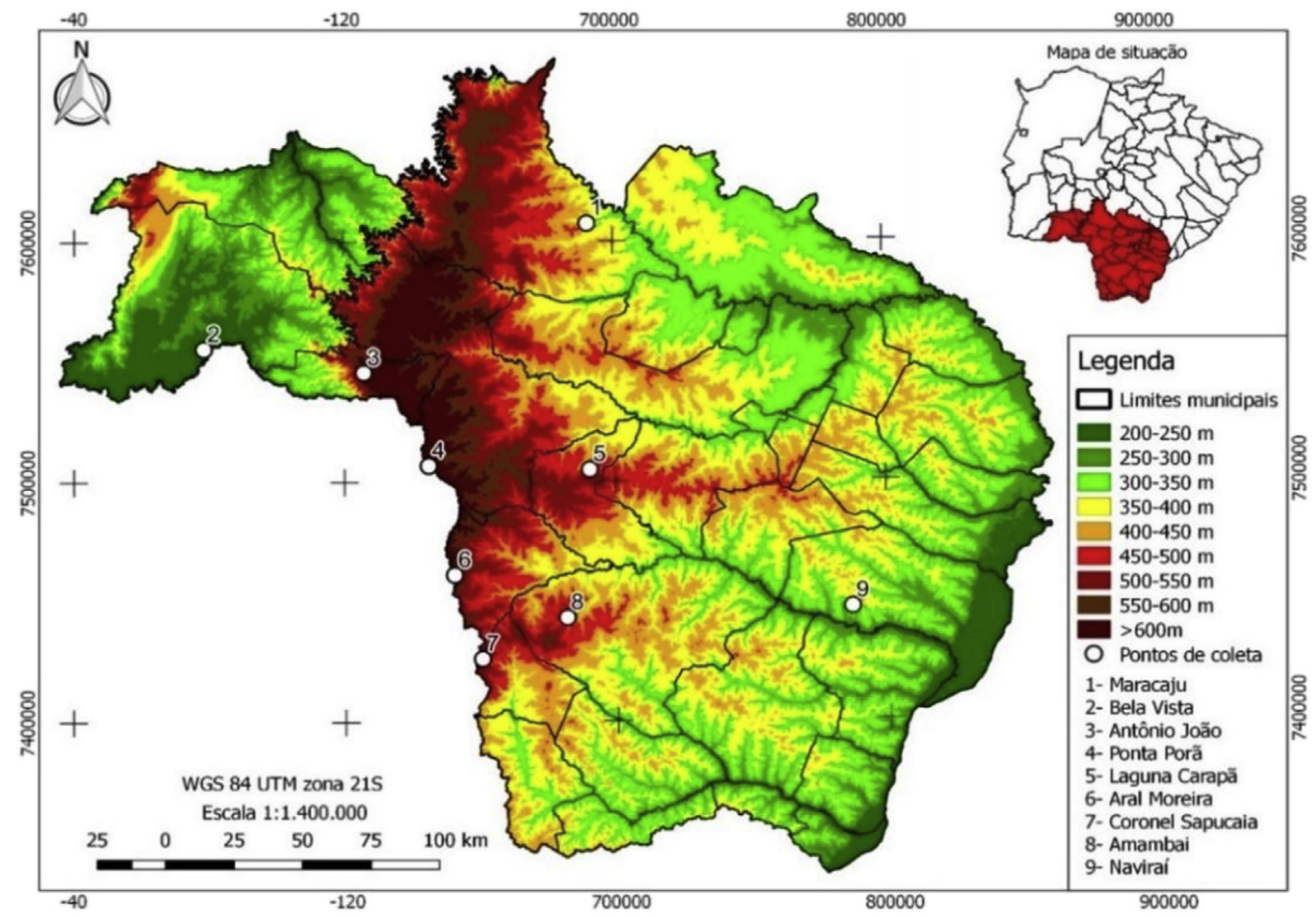

Fig. 1. Map showing the altitude of the cities evaluated in this study located in the southwest mesoregion of Mato Grosso do Sul. The sample points are highlighted. 
do Sul, Brazil. Then, infer possible abiotic agents that may contribute to the effects of atmospheric pollutants and finally map the cities with greater risks to the health of the local population.

\section{Materials and methods}

\subsection{Locations}

This study was conducted in nine cities located in the southwest mesoregion of Mato Grosso do Sul, Brazil; including the municipalities of Amambai, Antônio João, Aral Moreira, Coronel Sapucaia, Bela Vista, Laguna Caarapã, Maracaju, Naviraí, and Ponta Porã (Fig. 1).

\subsection{TRAD-MCN assay procedures}

The TRAD-MCN test was performed according to the protocol developed by Ma (1994). Fifteen young buds from ornamental plants of Tradescantia pallida (Rose) D.R. Hunt var. purpurea were collected bimonthly from each city during the months of August, October, and December of 2015, and February, April, June, and August of 2016. A mixture of the contents of the young buds/city was made and a sample was taken to prepare the slides. The buds were fixed in Carnoy's solution ( 3 ethyl alcohol: 1 acetic acid). After $24 \mathrm{~h}$, the inflorescences were transferred into a 70\% alcohol solution. Six slides were prepared using the bud samples collected from each city. The number of micronuclei in 300 tetrads per slide was counted using an optical microscope (Nikon YS2; Tokyo, Japan) at 400X magnification and the results were expressed as percentages (micronuclei frequency in 100 tetrads).

\subsection{Assessment of vehicular flow and environmental conditions}

Vehicular traffic was assessed in each city by counting the number of vehicles passing per hour at three different times of the day: from 8:00 to 9:00 a.m., from 11:00 to 11:59 a.m. and from 5:00 to 6:00 p.m. Subsequently, the average vehicular flow obtained at each city was calculated.

A hypsometric map was generated using digital elevation model data provided by the INPE's (National Institute for Space Research) TOPODATA project and the data was processed using GIS (Geographic Information System) software provided by Quantum GIS, version 2.6. Altitude ranges were calibrated in 50-m intervals from the base elevation, which was reported in TOPODATA.

The intensity map of pollutant incidence, based on the micronuclei frequency observed in different cities, was generated using the Kernel method. The Kernel method is an algorithm for pattern analysis that uses spatial interpolation of the points where the data was collected to generate a map that shows the dispersion intensity of the values in the area the data was collected. The continuous surface generated by the Kernel method interpolation maps the intensity of air pollution in the area. This allows the visual identification of the areas with the greatest concentration of pollutants.

Data consisting of the temperature $\left({ }^{\circ} \mathrm{C}\right)$, relative humidity $(\mathrm{RH})$, and pluviosity were obtained from local meteorological stations (Table 1).

\subsection{Statistical analysis}

The experimental design used for the statistical analysis was completely randomized using a factorial scheme with 9 cities, 7 periods, and with 6 replicates. The mean frequency of the number of pollutant affected micronuclei was evaluated using an F-test at $5 \%$ probability level. In cases where a significant difference was found, the means were compared using Tukey's test at $1 \%$

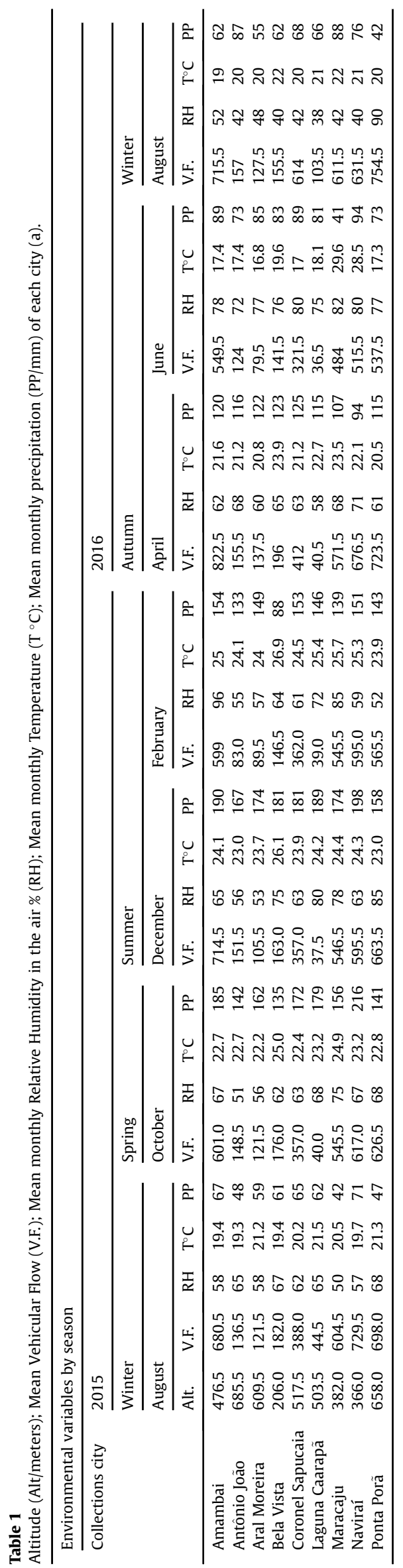


Table 2

Analysis of variance for MCN frequency in 9 cities and 7 periods in the southwestern mesoregion of Mato Grosso do Sul.

\begin{tabular}{lll}
\hline CV & DF & Mean Square \\
\cline { 3 - 3 } & & Micronucleus $(\mathrm{MCN})$ \\
\hline City & 8 & $304.630952^{* *}$ \\
Period & 6 & $378.116402^{* *}$ \\
City $\times$ Period & 48 & $32.390212^{\text {ns }}$ \\
Overall mean & - & 5.94 \\
\hline
\end{tabular}

**Significant at $1 \%$ probability by $\mathrm{F}$ test.

ns No significant.

DF: degrees of freedom.

$\mathrm{CV}$ : Cause of the variation.

probability level performed by SAS analysis software (2014).

Pearson's correlation analysis was performed for the following environmental variables: mean ambient temperature, altitude, relative humidity in air and pluviosity, vehicular flow and micronuclei frequency. The significance of the correlation analysis was assessed with a coefficient using a $t$-test at $5 \%$ probability level. Subsequently, a linear regression analysis of the micronuclei frequency was performed as a function of the flow of motor vehicles.

\section{Results}

The frequency of micronuclei was significantly influenced by the cities, as well as the different periods in which they were evaluated. However, no statistical significance was noted in the interaction between the two factors: city and period. Analysis are summarized in Table 2.

The analysis of the variation in the micronuclei frequency in the tetrads of T. pallida between the cities displayed three different groups. Amambai, Maracaju, Navirai and Bela Vista did not differ statistically from Ponta Porã, and are also similar to Antônio João and Coronel Sapucaia. Aral Moreira was equal to the cities previously mentioned, while Laguna Caarapã presented lower average (Fig. 2A).

The analysis of the periods showed that the months of August
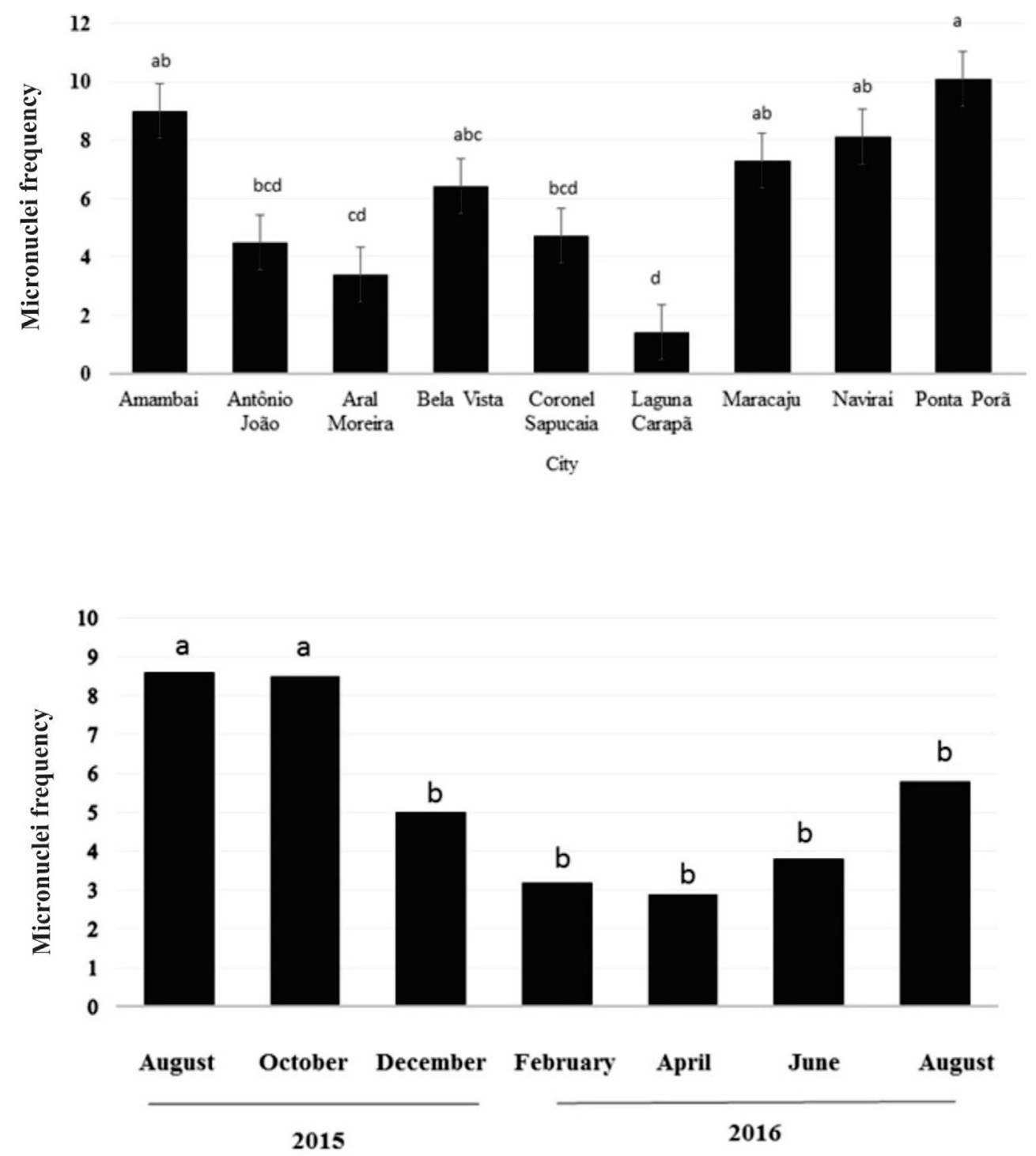

Months

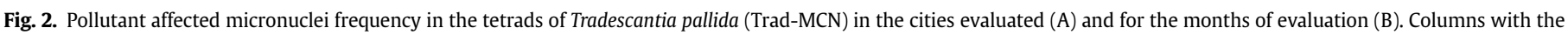
same letter do not differ statistically according to the Tukey's test at $1 \%$ probability. 


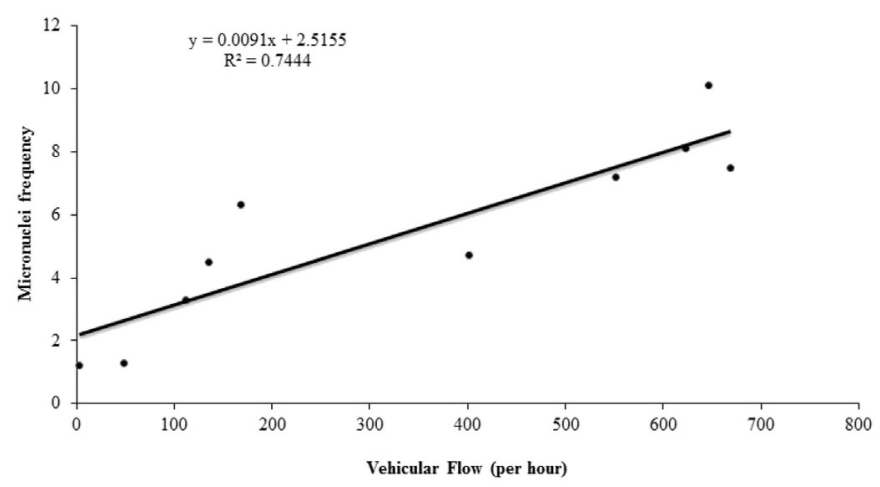

Fig. 3. Regression analysis between vehicular flow (cars/h) and micronuclei frequency of Tradescantia pallida.

and October 2015 had the highest micronuclei frequency averages, and this was true for all cities. The months of December 2015, February, April, June, and August of 2016 had lower frequencies of micronuclei, regardless of the city (Fig. 2B).

The average number of vehicles/h that circulated in the cities, in descending order was: $669,653,623,559,366,166,137,112$, and 49 in the cities of Amambai, Ponta Porã, Naviraí, Maracaju, Coronel Sapucaia, Bela Vista, Antônio João, Aral Moreira, and Laguna Caarapã, respectively. The cities with the highest intensity of motor vehicle traffic also showed the highest average micronuclei frequency in the tetrads of T. pallida. According to the linear regression model, the micronuclei frequency was positively influenced by vehicular flow (Fig. 3 and Table 3 ).

The average ambient temperature failed to show a linear association with the micronuclei frequency in the samples analyzed $\left(\mathrm{r}=0.11^{\mathrm{ns}}\right)$. A positive correlation was observed between micronuclei frequency and vehicular flow, $(\mathrm{r}=0.67 ; \mathrm{p} \leq 0.001 \%)$ and between micronuclei frequency and altitude $(\mathrm{r}=0.24 ; \mathrm{p} \leq 0.05)$. A negative correlation was found between relative humidity and micronuclei frequency $(\mathrm{r}=-0.19 ; \mathrm{p} \leq 0.05 \%)$. Thus, higher micronuclei frequency tended to be present in locations with low relative humidity and high altitudes and vehicular flow (Fig. 4).

Based on the micronuclei frequency in the different cities evaluated, it was possible to suggest a spatial distribution of pollution intensity in the cities (Fig. 5). It was possible to observe a higher pollution intensity in the red area, comprised of the cities of Ponta Porã, Naviraí, Amambai, and Maracaju. A lower intensity (orange area) was observed in the cities of Bela Vista, Antônio João, and Coronel Sapucaia. The blue regions represent the areas of low pollution intensity, such as Laguna Caarapã and Aral Moreira.

\section{Discussion}

The results of this study demonstrated that the concentration of mutagenic pollutants may be in the gaseous phase or adsorbed to particulate matter in the urban environments that were analyzed, and had an association with the environmental factor and altitude,

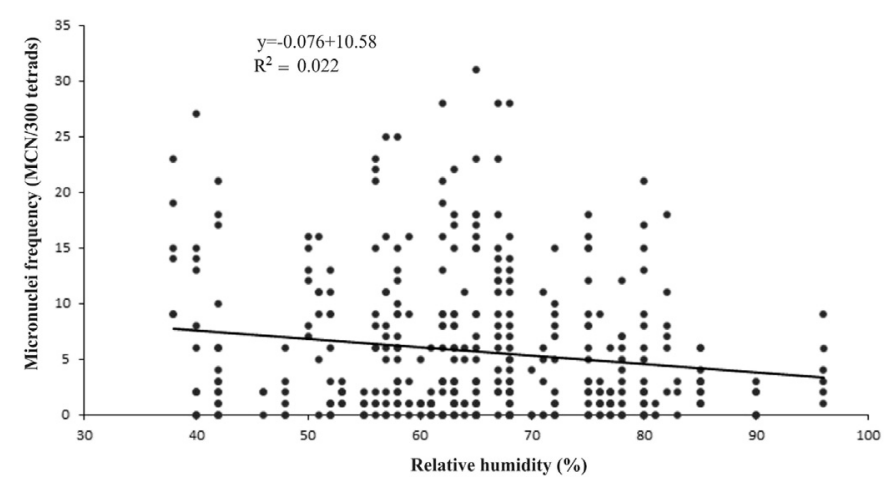

Fig. 4. Correlation between micronuclei frequency in pollen grains of Tradescantia pallida and the relative humidity of each point sampled in the cities evaluated.

which could directly influence the micronuclei frequency in Tradescantia pallida. This was clearly observed in the analysis of Ponta Porã, which presented an average flow of $653 \mathrm{cars} / \mathrm{h}$ and a higher average micronuclei frequency. The higher micronuclei frequencies are mainly due to vehicular flow emissions and not related to altitude, which is a covariant of traffic flow.

The city of Ponta Porã borders the city of Pedro Juan Caballero, Paraguay. Several motor vehicles transit between cities, originating from different locations in the country. Ponta Porã is located at the border of the Maracaju mountain range at a high altitude, and it maintains a relative humidity of approximately $90 \%$ in the winter. During in loco visits, it was observed that Ponta Porã had intense vehicular traffic, which maximizes and extends the coverage area of the pollutants in the city, thereby increasing the observed micronuclei frequency. Ponta Porã is characterized by low temperature days, forming a layer of stationary cold air that is covered by a layer of stationary warm air (Zavattini, 2009). The consequence of this phenomenon is a higher concentration of pollutant gases emitted in the urban areas, which contributes to the smog phenomenon. This phenomenon may have contributed to the higher frequencies of micronuclei observed in Ponta Porã at an altitude of $658 \mathrm{~m}$. This phenomenon has also been observed in the city of Antônio João but, due to low vehicular flow in this municipality (an average 137 vehicles/h), a high micronuclei frequency was not observed.

The city of Naviraí is located at the region bordering the state of Paraná and São Paulo, and, although it is not located at a high altitude, in contrast to the other cities analyzed, the vehicular traffic is intense due to a major highway (BR-163) that connects several municipalities. Amambai is bordered by Paraguay, and has a high vehicular flow as a result of the several state highways passing through the city (MS 156; 165; 286; 289; 295, and 386). The city of Maracaju is also connected via the BR 163, which also has a high flow of vehicles. This high vehicular traffic explains the increase in the micronuclei frequency observed and the high incidence of pollutants mapped using the Kernel technique.

It is important to point out that all the cities have agriculture as a major economic activity, resulting in heavy vehicular traffic

Table 3

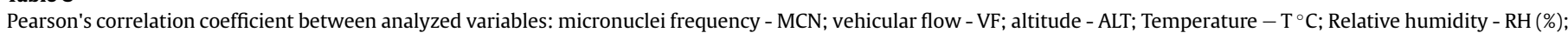
Pluviosity - PLU (mm).

\begin{tabular}{|c|c|c|c|c|c|c|}
\hline & MCN & ALT & $\mathrm{RH}$. & TEMP & PLU & $\mathrm{VF}$ \\
\hline $\mathrm{MCN}$ & & $0.24 ; \mathrm{p} \leq 0.05$ & $-0.19 ; \mathrm{p} \leq 0.02$ & $0.11 ; \mathrm{p} \leq 0.20$ & $-0.46 ; \mathrm{p} \leq 0.62$ & $0.67 ; p \leq 0.001$ \\
\hline ALT & & & $-0.32 ; \mathrm{p} \leq 0.02$ & $-0.32 ; \mathrm{p} \leq 0.00$ & $0.38 ; \mathrm{p} \leq 0.10$ & $0.270 ; \mathrm{p} \leq 0.04$ \\
\hline $\mathrm{RH}$ & & & & $-0.22 ; \mathrm{p} \leq 0.00$ & $0.06 ; \mathrm{p} \leq 0.11$ & $-0.05 ; \mathrm{p} \leq 0.54$ \\
\hline TEMP & & & & & $0.33 ; \mathrm{p} \leq 0.25$ & $0.09 ; \mathrm{p} \leq 0.31$ \\
\hline PLU & & & & & & $-0.45 ; \mathrm{p} \leq 0.63$ \\
\hline
\end{tabular}




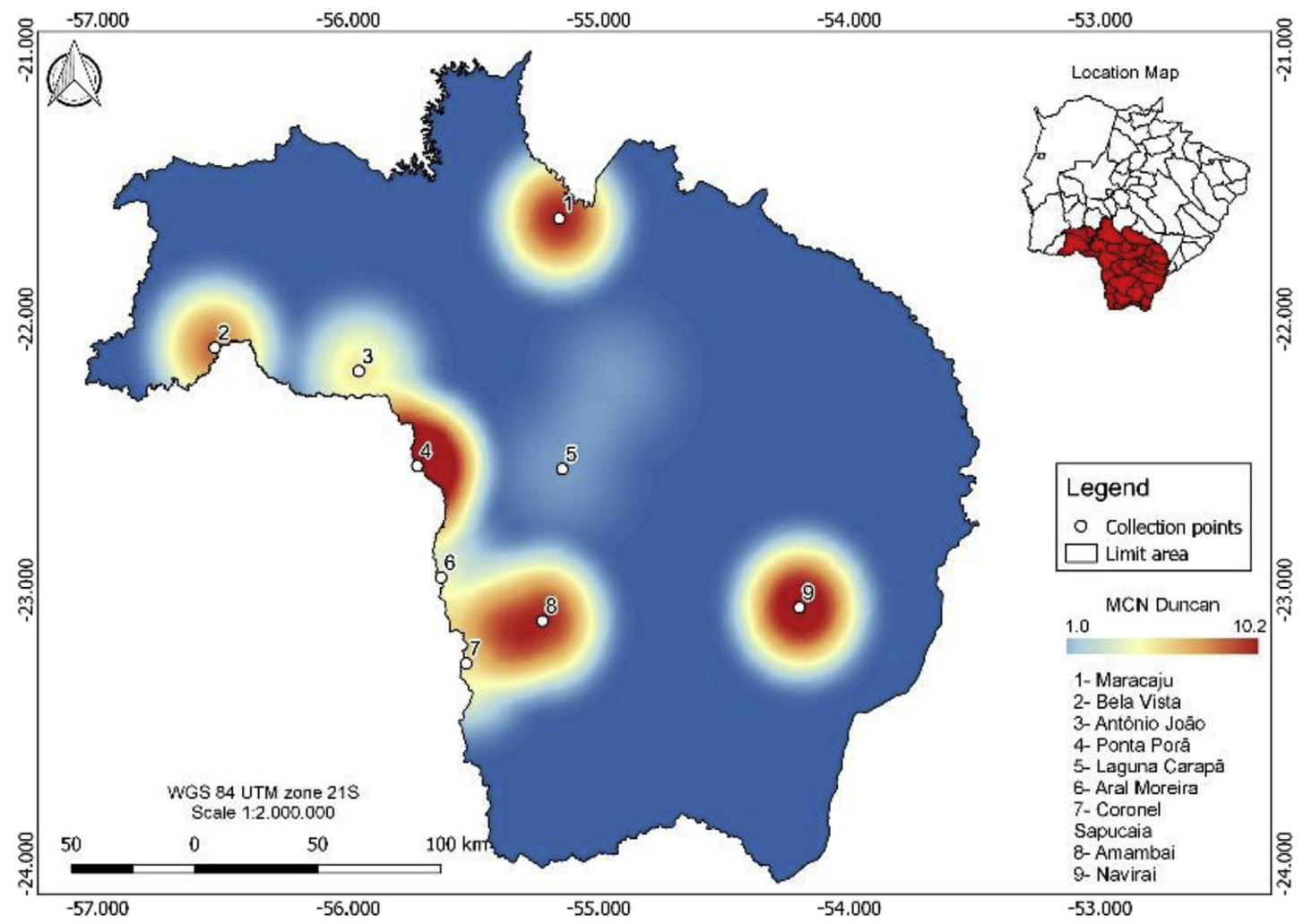

Fig. 5. Kernel map indicating the spatial distribution of pollution intensity in the cities.

consisting of cargo trucks and even larger vehicles. This significantly affects the air quality. According to Teixeira et al. (2008), heavy vehicles account for the largest fraction of nitrogen oxide and sulfur emissions, with diesel fuel being the worst pollutant.

Spósito et al. (2017) analyzed cities in the microregion of Mato Grosso do Sul, the altitude ranges of the cities were very similar (318 $\mathrm{m}-470.2 \mathrm{~m}$ ) and relationships between altitude and genetic damages did not show any significant correlation. The cities analyzed in this study, located in the mesoregion of the same state, had greater altitudes, ranging between $206 \mathrm{~m}$ and $658 \mathrm{~m}$. There was a significant tendency and positive correlation between altitude and micronuclei frequency $(\mathrm{r}=0.24 ; \mathrm{p} \leq 0.05)$, and negative tendency correlation for relative humidity $(\mathrm{r}=-0.19 ; \mathrm{p} \leq 0.05 \%)$. This indicated a trend of a higher micronuclei frequency in localities with low relative humidity and high altitudes.

In this study, the periods that showed the highest micronuclei frequency were August and October of 2015 (winter and spring). The environmental conditions during these periods were characterized by low temperatures and low relative humidity, which may lead to a higher molecular weight of the atmospheric pollutant. Similarly, studies report a higher mutagenic potential in colder months in European countries (Binková et al., 2003; Du Four et al., 2004; Piekarska et al., 2009, 2011), North and South America (Brown et al., 2006; Cavanagh et al., 2009) and New Zealand (Török et al., 1989; Müller et al., 2001).

In the present study, the relative humidity was an important variable in micronuclei frequency, demonstrating a trend with a negative linear correlation. These results are consistent with those observed by Spósito et al. (2017) in the microregion of Dourados, where the micronuclei in $T$. pallida decreased as the relative humidity increased. Thus, this result is of great value, since the vehicular flow at each sampling site did not show large variations throughout the sample period, so the observed micronuclei frequency are interrelated to environmental factors. The biological response of plants linked to environmental conditions have also been reported by Klumpp et al. (2004) and Crispim et al. (2012). According to Costa and Droste (2012) and Spósito et al. (2015), genetic damage in plants located in urban areas was associated with large vehicular fleets and high concentrations of air pollutants. Casera and Blasior (2001) observed high mutation rates using the Trad-MCN test in the city of Bolzano, Italy, in areas near highways. Batalha et al. (1999) and Guimarães et al. (2004) carried out studies in the city of São Paulo and confirmed the high sensitivity of the Tradescantia genus to atmospheric pollutants in a general way, since in this study the particulate material was not measured, which makes impossible to confirm the biological response of the plant to the pollutant.

The genotoxic effects on T. pallida can be used to infer risks on human health due to air pollution. Studies have associated the micronuclei frequency with cardiorespiratory diseases in areas of heavy traffic (Alves et al., 2001; Sumita et al., 2003; Mariani et al., 2009). According to Demarini (2013), populations living or working near highways are at high risk of cancer and cardiovascular diseases, asthma, decreased lung function, allergies, and complications during childbirth. The Trad-MCN bioassay can be used to alert inhabitants of these potential risks. In addition, the bioassay is easy to use and has a low initial investment cost.

Studies that investigate the effect of air pollution on the quality of life of the population and proposing control measures are recommended for high vehicular flow cities, which present greater mutagenic potential.

This study indicated that cities with heavy vehicular flow showed a higher frequency of mutagenic alterations in the micronuclei of Tradescantia pallida and the abiotic conditions that statistically demonstrated tendencies to potentiate these alterations are relative humidity and altitude. Air pollution was more intense 
in the city of Ponta Porã.

\section{Acknowledgements}

The authors would like to thank the Federal University of Grande Dourados (UFGD) for the logistic support, and the Foundation for the Support and Development of Education, Science, and Technology (FUNDECT) of the state of Mato Grosso do Sul for the financial support (Process: 23/200.838/2). In addition, we would like to thank the Coordination for the Improvement of Higher Education Personnel (CAPES) for the grant awarded to the first author.

\section{References}

Alves, E.S., Giusti, P.M., Domingos, M., Saldiva, P.H.N., Guimarães, E.T., Lobo, D.J.A., 2001. Estudo anatômico foliar do clone híbrido 4430 de Tradescantia: alteraçôes decorrentes da poluição aérea urbana. Rev. Bras. Bot. 24, 567-576. https://doi. org/10.1590/S0100-84042001000500012.

Andrade Jr., S.J., Santos Jr., J.C.S., Oliveira, J.L., Cerqueira, E.M.M., Meireles, J.R.C., 2008. Micronúcleos em tétrades de Tradescantia pallida (Rose) Hunt. cv. purpurea Boom: alterações genéticas decorrentes de poluição aérea urbana. Acta Sci. Biol Sci. 30 (3), 295-301. https://doi.org/10.4025/actascibiolsci.v30i3.5017.

Batalha, J.R.F., Guimaraes, E.T., Lobo, D.J.A., Lichtenfels, A.J.F., Deur, T., Carvalho, H.A., Alves, E.S., Domingos, M., Rodrigues, G.S., Saldiva, P.H.N., 1999. Exploring the clastogenic effects of air pollutants in Sao Paulo (Brazil) using the Tradescantia micronuclei assay. Mutat. Res. 426, 229-232. https://doi.org/10.1016/S00275107(99)00073-1.

Bernstein, J.A. Alexis, N., Barnes, C., Bernstein, I.L., Nel, A., Peden, D., DiazSanchez, D., Tarlo, S.M., Williams, P.B., 2004. Health effects of air pollution. J. Allergy Clin. Immunol. 114 (5), 1116-1123.

Binková, B., Černá, M., Pastorková, A., Jelınek, R., Beneš, I., Novák, J., Šrám, R.J., 2003. Biological activities of organic compounds adsorbed onto ambient air particles: comparison between the cities of Teplice and Prague during the summer and winter seasons 2000-2001. Mutat. Res. 525 (1), 43-59. PMID: 12650904.

Boström, C.E., Almén, J., Steen, B., Westerholm, R., 1994. Human exposure to urban air pollution. Environ. Health Perspect. 102, 39-47. PMC1566930.

Brown, S.S., Ryerson, T.B., Wollny, A.G., Brock, C.A., Peltier, R., Sullivan, A.P., Dubé, W.P., Fehsenfeld, F.C., Ravishankara, A.R., 2006. Variability in nocturnal nitrogen oxide processing and its role in regional air quality. Science 311 (5757), 67-70. https://doi.org/10.1126/science.1120120.

Brito, K.C.T., Lemos, C.T., Rocha, J.A.V., Mielli, A.C., Matzenbacher, C., Vargas, V.M.F., 2013. Comparative genotoxicity or airborne particulate matter (PM2.5) using Salmonella, plants and mammaliam cells. Ecotoxicol. Environ. Saf. 94, 14-20. https://doi.org/10.1016/j.ecoenv.2013.04.014.

Casera, M., Blasior, P., 2001. Luftverschmutzung und Mutagenität in der Stadt Bozen. Schriftenreihe der Agentur für Umwelt- und Arbeitsschutz, Bolzano. Italy Erhebungszeitraum 1999-2000 (9), 111.

Cavanagh, J.A.E., Zawar-Reza, P., Wilson, J.G., 2009. Spatial attenuation of ambient particulate matters air pollution within an urbanized native forest patch. Urban For. Urban Green 8 (1), 21-30. https://doi.org/10.1016/j.ufug.2008.10.002.

Claxton, L.D., Matthews, P.P., Warren, S.H., 2004. The genotoxicity of ambient outdoor air, a review: Salmonella mutagenicity. Mutat. Res. 567 (2), 347-399. https://doi.org/10.1016/j.mrrev.2004.08.002.

Claxton, L.D., Woodall Jr., G.M., 2007. A review of the mutagenicity and rodent carcinogenicity of ambient air. Mutat. Res. 636, 36-94. https://doi.org/10.1016/j. mrrev.2007.01.001.

Cohen, A.J., Anderson, H.R., Ostro, B., Pandey, K.D., Krzyzanowski, M., Kuenzli, N., Gutschmidt, K., Pope, C.A., Romieu, I., Samet, J.M., Smith, K.R., 2004. Mortality impacts of urban air pollution. In: Ezzati, M., Rodgers, A.D., Lopez, A.D., Murray, C.J.L. (Eds.), Comparative Quantification of Health Risks: Global and Regional Burden of Disease Due to Selected Major Risk Factors, Vols. 2 of 3. World Health Organization, Geneva, pp. 1353-1433.

Costa, G.M., Droste, A., 2012. Genotoxicity on Tradescantia pallida var. purpurea plants exposed to urban and rural environments in the metropolitan area of Porto Alegre, southern Brazil. Braz. J. Biol. 72, 801-806.

Crispim, B.A., Spósito, J.C.V., Mussury, R.M., Seno, L.O., Grisolia, A.B., 2014. Effects of atmospheric pollutants on somatic and germ cells of Tradescantia pallida (Rose) DR HUNT cv. purpurea. An. Acad. Bras. Ciênc 86 (4), 1899-1906.z. https://doi. org/10.1590/0001-3765201420140338.

Crispim, B.A., Vaini, J.O., Grisolia, A.B., Teixeira, T.Z., Mussury, R.M., Seno, L.O., 2012. Biomonitoring the genotoxic effects of pollutants on Tradescantia pallida (rose) DR hunt in Dourados. Brazil. Environ. Sci. Pollut. Res. 19 (3), 718-723. https:// doi.org/10.1007/s11356-011-0612-3.

Da Costa, G.M., Petry, C.T., Droste, A., 2016. Active versus passive biomonitoring o fair quality: genetic damage and bioaccumulation of trace elements in flower buds of Tradescantia pallida. Water, Air, Soil Pollut. 227 (7), 1-12. https://doi. org/10.1007/s11270-016-2923-y.

Dapper, S.N., Spohr, C., Zanini, R.R., 2016. Poluição do ar como fator de risco para a saúde: uma revisão sistemática no estado de São Paulo. Estud. Avançados 30 (86), 83-97.
Demarini, D.M., 2013. Genotoxicity biomarkers associated with exposure to traffic and near-road atmospheres: a review. Mutagen 28, 485-505. http://doi:10. 1093/mutage/get042.

Du Four, V.A., Van Larebeke, N., Janssen, C.R., 2004. Genotoxic and mutagenic activity of environmental air samples in Flanders. Belgium. Mutat. Res. 558 (1), 155-167. https://doi.org/10.1016/j.mrgentox.2003.12.002.

Ennever, F.K., Andreano, G., Rosenkranz, H.S., 1988. The ability of plant genotoxicity assay to predict carcinogenicity. Mutat. Res. $205(1-4), 99-105$. https://doi.org 10.1016/0165-1218(88)90013-4.

Fagundes, M.B.B., Gianetti, G.W., Oliveira, D.V., Dias, D.T., da Silva, L.C., 2017. Desenvolvimento Econômico do Estado de Mato Grosso do Sul Uma Análise da Composição da Balança Comercial. DESENVOL. QUESTÃO. Editora Unijuí 15 (39), 112-140. https://doi.org/10.21527/2237-6453.2017.39.112-140.

Gouveia, N., Corrallo, F.P., Leon, A.C.P.D., Junger, W., Freitas, C.U.D., 2017. Poluição do ar e hospitalizações na maior metrópole brasileira. Rev. Saude Publica 51, 1-10. https://doi.org/10.11606/S1518-8787.20170510002231.

Grant, W.F., Lee, H.G., Logan, D.M., Salamone, M.F., 1992. The use of Tradescantia and Vicia faba bioassays for the in situ detection of mutagens in an aquatic environment. Mutat. Res. 270 (1), 53-64. https://doi.org/10.1016/0027-5107(92) 90101-7.

Grant, W.F., 1998. Higher plant assays for the detection of genotoxicity in air polluted. Environ. Ecosys. Health 4 (4), 210-229. https://doi.org/10.1016/S00275107(99)00050-0I.

Guimarães, E.T., Macchione, M., Lobo, D.J., Domingos, M., Saldiva, P.H.N., 2004. Evaluation of the mutagenic potential of urban air pollution in São Paulo, Southeastern Brazil, using the Tradescantia stamen-hair assay. Environ. Toxicol. 19 (6), 578-584. https://doi.org/10.1002/tox.20065.

Ianisticki, M., Dallarosa, J., Sauer, C., Teixeira, C.E., Da Silva, J., 2009. Genotoxic effect of polycyclic aromatic hydrocarbons in the metropolitan area or Porto Alegre, Brazil, evaluated by Helix aspera (Müller, 1974). Environ. Pollut. 157, 2037-2042. https://doi.org/10.1016/j.envpol.2009.02.025.

International Agency For Research On Cancer - IARC, 2016. Monographs on the Evaluation of Carcinogenic Risks to Humans. Outdoor Air Pollution, v. 109, Lyon, France.

International Agency For Research On Cancer - IARC, 2013. Monographs on the Evaluation of Carcinogenic Risks to Humans: Diesel and Gasoline Engine Exhausts and Some Nitroarenes IARC Monograph, vol. 105. IARC, Lyon, France.

International Agency For Research On Cancer - IARC, 2010. Monographs on the Evaluation of Carcinogenic Risks to Humans: Household Use of Solid Fuels and High-temperature Frying IARC Monograph, vol. 95. IARC, Lyon, France.

Klumpp, A., Klumpp, G., Ansel, W., 2004. Urban air quality in Europe - results of three years of standardized biomonitoring studies. Pp: 25-50. In: Klumpp, A., Ansel, W., Klumpp, G. (Eds.), Urban Air Pollution, Bioindication and Environmental Awareness. Cuvillier Verlag, Göttingen.

Lewtas, J., 1993. Experimental evidence for carcinogenity of air pollutants. In: Tomatis, L. (Ed.), Air Pollution and Human Cancer, Monographs, European School of Oncology. Springer-Verlag, New York, pp. 49-61.

Ma, T.H., Cabrera, G.L., Chen, R., Gill, B.S., Sandhu, S.S., Vandenberg, A.L., Salamone, M.F., 1994. Tradescantia micronucleus bioassay. Mutat. Res. 310, 221-230.

Ma, T.H., 1981. Tradescantia micronucleus bioassay and pollen tube chromatid aberration test for in situ monitoring and mutagen screening. Environ. Health Perspect. 37, 85-90. https://doi.org/10.2307/3429254.

Ma, T.H., 1983. Tradescantia micronuclei (Trad-MN) test for environmental clastogens. In: Kolber, A.R., Wong, T.K., Grant, Lester, D., DeWoskin, Robert, S., Hughes, J.T. (Eds.), In Vitro Toxicity Testing of Environmental Agents. Plenum Publishing Corporation, New York, pp. 1191-1214.

Mariani, R.L., Jorge, M.P.M., Pereira, S.S., Melione, L.P., Carvalho-Oliveira, R., Ma, T.H. Saldiva, P.H.N., 2009. Association between micronuclei frequency in pollen mother cells of Tradescantia and mortality due to cancer and cardiovascular diseases: a preliminary study in Sao José dos Campos, Brazil. Environ. Pollut. 157, 1767-1770. https://doi.org/10.1016/j.envpol.2009.02.023.

Meireles, J.R., Cerqueira, E.M.M., 2011. Use of the micronucleus test on Tradescantia (Trad-MCN) to evaluate the genotoxic fffects of air pollution. Air Pollut. - New Develop. 1, 245-262.

Mielli, A.C., Matta, M.E.M., Nersesyan, A., Saldiva, P.H.N., Umbuzeiro, G.A., 2009. Evaluation of the genotoxicity of treated urban sludge in the Tradescantia micronucleus assay. Mutat. Res. 672, 51-54. PMid:18940264. https://doi.org/10. 1016/j.mrgentox.2008.09.007.

Misík, M., Micieta, K., Solenská, M., Misíková, K., Pisarcíková, H., Knasmüller, S., 2007. In situ biomonitoring of the genotoxic effects of mixed industrial emissions using the Tradescantia micronucleus and pollen abortion tests with wild life plants: demonstration of the efficacy of emission controls in an eastern European city. Environ. Pollut., Barking 145 (2), 459-466.

Mišik, M., Solenská, M., Mičieta, K., Mišiková, K., Knasmüller, S., 2006. In situ monitoring of clastogenicity of ambient air in Bratislava, Slovakia using the Tradescantia micronucleus assay and pollen abortion assays. Mutat. Res. 605 (1), 1-6. https://doi.org/10.1016/j.mrgentox.2005.12.009.

Müller, A., Alzuet, P., Herbarth, O., Ronco, A., 2001. Assessment of toxicity and mutagenicity in air particulate matter from an urban industrial area in the coast of the Rio de la Plata. Environ. Toxicol. 16 (2), 151-157. https://doi.org/10.1002/ tox.1019.

Nascimento, A.P., Santos, J.M., Mill, J.G., Souza, J.B.D., Júnior, R., Costa, N., Reisen, V.A., 2017. Association between the concentration of fine particles in the atmosphere and acute respiratory diseases in children. Rev. Saúde Publ. 51 (0), 3. https:// 
doi.org/10.1590/S1518-8787.2017051006523.

Nyberg, F. Gustavsson, P., Jarup, L., Bellander, T., Berglind, N., Jakobsson, R. Pershagen, G., 2000. Urban air pollution and lung cancer in Stockholm. Epidemiol 11 (5), 487-495. PMID: 10955399.

Pereira, T.S., Gotor, G.N., Beltrami, L.S., Nolla, C.G., Rocha, J.A.V., Broto, F.P. Comellas, L.R., Vargas, V.M.F., 2010. Salmonella mutagenicity assessment of airborne particulate matter collected from urban areas of Rio Grande do Sul State Brazil, differing in anthropogenic influences and polycyclic aromatic hydrocarbon levels. Mutat. Res. 702, 78-85. https://doi.org/10.1016/j.mrgentox. 2010.07.003.

Piekarska, K., Zaciera, M., Czarny, A., Zaczyńska, E., 2009. Mutagenic and cytotoxic properties of extracts of suspended particulate matter collected in Wrocław city area. Environ. Protect. Eng. 35 (1), 37-48.

Piekarska, K., Zaciera, M., Czarny, A., Zaczyńska, E., 2011. Application of short-term tests in assessment of atmospheric air pollution. Environ. Protect. Eng. 37 (2), $85-98$

Rodrigues, G.S., Ma, T.H., Pimentel, D., Weinstein, L.H., Ichikawa, S., 1997. Tradescantia bioassays as monitoring systems for environmental mutagenesis - a review. Crit. Ver. Plant. Sci. 16 (4), 325-359.

Saldiva, P.H.N., Clarke, R., Coull, B.A., Stearns, R.C., Lawrence, J., Murthy, G.G.K. Diaz, E., Koutrakis, P., Suh, H., Tsuda, A., Godleski, J.J., 2002. Lung inflammation induced by concentrated ambient air particles is related to particle composition. Am. J. Respir. Crit. Care Med. 165 (12), 1610-1617. DOI: 0.1164/ rccm.2106102.

Santos, A.P.M., Segura-Muñoz, S.I., Nadal, M., Schuhmacher, M., Domingo, J.L. Martinez, C.A., Takayanagui, A.M.M., 2015. Traffic-related air pollution biomonitoring with Tradescantia pallida (Rose) Hunt. cv. purpurea Boom in Brazil. Environ. Monit. Assess. 187 (2), 39. https://doi.org/10.1007/s10661-014-4234-3.

SAS, 2014. Institute Inc. Statistical Analysis System user's guide. Version 9.0. Cary
Statistical Analysis System Institute, 513p.

Spósito, J.C.V., Crispim, B.A., Mussury, R.M., Grisolia, A.B., 2015. Genetic instability in plants associated with vehicular traffic and climatic variables. Ecotoxicol. Environ. Saf. 120, 445-448. https://doi.org/10.1016/j.ecoenv.2015.06.031.

Spósito, J.C.V., Crispim, B.D.A., Romãn, A.I., Mussury, R.M., Pereira, J.G., Seno, L.O., Grisolia, A.B., 2017. Evaluation the urban atmospheric conditions in different cities using comet and micronuclei assay in Tradescantia pallida. Chemosphere 175, 108-113. https://doi.org/10.1016/j.chemosphere.2017.01.136.

Sumita, N.M. Mendes, M.E Macchione, M. Guimarães, E.T, Lichtenfels, A.JFC. Lobo, D.A., Saldiva, P.H.N., 2003. Tradescantia pallida cv. purpurea boom in the characterization of air pollution by accumulation of trace elements. J. Air Waste Manag. Assoc. 53, 574-579. PMID: 12774990.

Teixeira, E.C., Feltes, S., Santana, E.R.R. 2008. Estudo das emissões de fontes móveis na região metropolitana de Porto Alegre, Rio Grande do Sul. Quím. Nova 31 (2), 244-248. https://doi.org/10.1590/S0100-40422008000200010.

Török, G. Csik, M. Kertesz, M. Fay, E. Somorjay, T, Börzsönyi, M., Surjan, A. Kelecsenyi, Zs, Pinter, A., 1989. Mutagenicity and PAH content of airborn particulates and of fallen dusts from two Hungarian towns and emission samples from aluminum reduction and power plants. Ann. Ist. Super Sanita 25 (4), 595-599. PMID: 2631626.

Vargas, V.M.F., 2003. Mutagenic activity as a parameter to asses ambient air quality for protection of the environment and human health. Mutat. Res. 544, 313-319. https://doi.org/10.1016/j.mrrev.2003.06.020.

Wen Cheng, Y.W., Lee, H., 2003. Environmental exposure and lung cancer among nonsmokers: an example of Taiwanese female lung cancer. J. Environ. Sci. Health 21 (1), 1-28. https://doi.org/10.1081/GNC-120021371.

Zavattini, J.A. 2009. As Chuvas e as Massas de Ar no Estado de Mato Grosso do Sul: Estudos Geográficos com Vista à Regionalização Climática. São Paulo. Cultura Acadêmica, p. 131 